\title{
Perancangan Geometri Ruas Jalan Gudang Cijambu STA 1+400 s/d STA 3+400 Menggunakan AutoCAD Civil 3D 2018
}

\author{
ELKHASNET, NISA FAHIRA SABILLAH \\ Program Studi Teknik Sipil Institut Teknologi Nasional Bandung \\ Email: elkha@itenas.ac.id
}

\begin{abstract}
ABSTRAK
Ruas jalan Gudang-Cijambu STA $1+400$ s.d STA $3+400$ di Sumedang, Jawa Barat berperan sebagai sektor penghubung distribusi hasil pertanian dari desa ke kota dan penunjang laju pertumbuhan ekonomi pedesaan. Dilakukan perancangan geometrik jalan baru menggunakan software AutoCAD Civil 3D yang mengacu pada AASHTO 2004 dan dibandingkan volume galian dan timbunan dengan perancangan konsultan. Hasil perancangan jalan baru secara manual dan menggunakan AutoCAD Civil 3D menghasilkan 9 lengkung horizontal sedangkan perancangan konsultan sebanyak 22 lengkung horizontal. Perancangan ulang menghasilkan panjang trase yang semula $2.000 \mathrm{~m}$ menjadi $1.747,41 \mathrm{~m}$. Perancangan menggunakan data konsultan didapat selisih jumlah volume galian dan timbunan sebanyak 135.209,48 m³, ini lebih banyak dari perencanaan ulang dengan AutoCAD Civil 3D dimana selisih jumlah volume galian dan timbunan sebanyak $11.398,85 \mathrm{~m}^{3}$. Dengan AutoCAD, perancangan semakin mudah dan efisien dalam memilih trase.
\end{abstract}

Kata Kunci : perancangan geometri jalan, trase, galian, timbunan

\begin{abstract}
The Gudang-Cijambu road section STA $1+400$ s.d STA $3+400$ in Sumedang, West Java acts as a connecting sector for the distribution of agricultural products from villages to cities and to support the rate of rural economic growth. In this study, a new geometric road design was carried out using AutoCAD Civil 3D software which refers to AASHTO 2004 and will compare the volume of excavation and fill with consultant design. The results of manual redesign and using AutoCAD Civil 3D resulted in 9 horizontal curves while consultant design was 22 horizontal curves. Changes in the number of bends and differences in PI coordinate points resulted in the length of the original line of 2,000 $\mathrm{m}$ to $1,747.41 \mathrm{~m}$. Design using consultant data obtained a difference of $135,209.48 \mathrm{~m}^{3}$ of excavated and stockpile volume, more than the redesign with a difference of $11,398.85 \mathrm{~m}^{3}$ of excavated and stockpiled volume. With AutoCAD, design will be easier and more efficient to choose line.
\end{abstract}

Keywords : geometric road design, line, excavated, stockpile 


\section{PEndahuluan}

Ruas jalan Gudang - Cijambu berada di lokasi Kabupaten Sumedang, Jawa Barat seperti pada Gambar 1. Ruas jalan Gudang - Cijambu memiliki peranan penting sebagai sektor perhubungan untuk pendistribusian barang yang berkesinambungan berupa hasil pertanian masyarakat ke kota. Selain itu, ruas jalan Gudang - Cijambu juga menopang laju pertumbuhan ekonomi seiring dengan peningkatan kebutuhan sarana transportasi sehingga mampu menjangkau daerah pegunungan dan pedesaan.

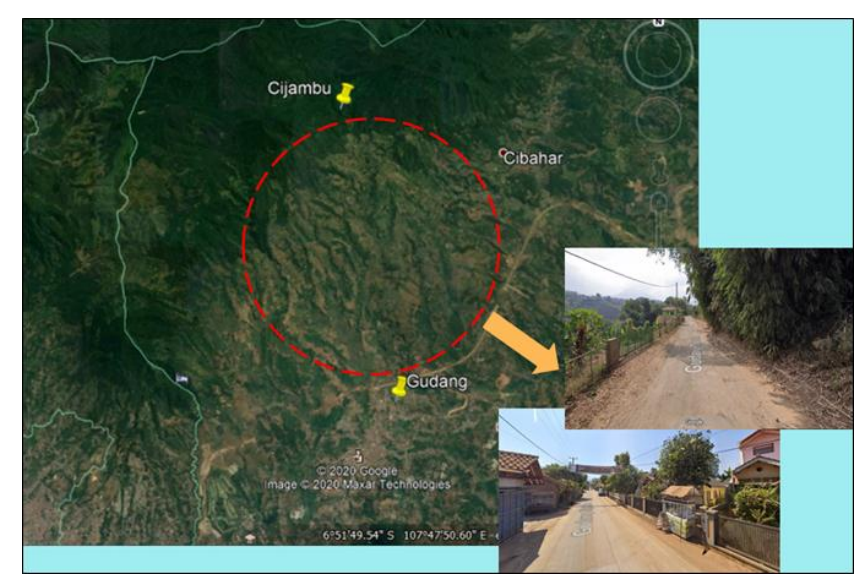

\section{Gambar 1. Lokasi ruas jalan Gudang - Cijambu} (Sumber: Google Earth, 2020)

Perancangan geometri ruas jalan Gudang - Cijambu dilakukan oleh PT. Kriyasa Abdi Nusantara, memiliki 3 segmen ruas jalan. Segmen pertama (STA. 00+600 - STA. 04+200) menghubungkan jalan Parigi dan jalan Kertasari dengan jalan Cikawung; segmen kedua (STA. 04+550 - STA. 05+000) menghubungkan jalan Cikawung dengan ruas jalan Lebak - Petak; segmen ketiga Petak (STA. 05+050 - STA. 09+305,524) menghubungkan ruas jalan Lebak Petak dengan ruas jalan Raya Cirebon - Bandung.

Perancangan geometri jalan pada penelitian ini hanya pada segmen 1 ruas jalan Gudang Cijambu (STA. 01+400 - STA. 03+400) yang mencakup pemilihan trase, perancangan alinyemen horizontal dan vertikal, penggambaran diagram superelevasi, penggambaran potongan memanjang dan melintang jalan, serta perhitungan volume timbunan dan galian. Serta, dikerjakan dengan bantuan software AutoCAD Civil 3D 2018.

Volume galian dan timbunan perancangan geometrik jalan baru menggunakan software AutoCAD Civil 3D 2018 dibandingkan dengan hasil volume galian dan timbunan perancangan konsultan PT. Kriyasa Abdi Nusantara menggunakan metode AASHTO 2004. Dalam perancangan geometrik jalan baru, penarikan trase jalan diusahakan tidak memotong kontur tetapi mengikuti kontur dengan elevasi yang sama sehingga menghasilkan selisih volume galian dan timbunan lebih sedikit.

\section{TINJAUAN PUSTAKA}

\subsection{Alinyemen Horizontal}

Menurut (Hendarsin, 2000), secara umum dalam perancangan alinyemen horizontal akan dijumpai 2 (dua) jenis bagian jalan yaitu bagian lurus dan bagian lengkung atau tikungan. 
Tikungan terdiri dari 3 (tiga) jenis yaitu Full Circle (FC), Spiral - Circle - Spiral (S-C-S) dan Spiral-Spiral(S-S).

\subsubsection{Lengkung Lingkaran Penuh (FC)}

Menurut (AASHTO, 2004), lengkung horizontal FC terdiri dari satu busur lingkaran saja dan tanpa lengkung peralihan seperti terlihat pada Gambar 2. Dengan tidak tersedianya tempat transisi atau peralihan dari kemiringan melintang di jalan lurus ke superelevasi, maka lengkung horizontal berbentuk lingkaran ini hanya diperkenankan untuk lengkung dengan radius yang besar dimana pergeseran tangen ke bagian lengkung $(p)$ maksimum 0,2 m.

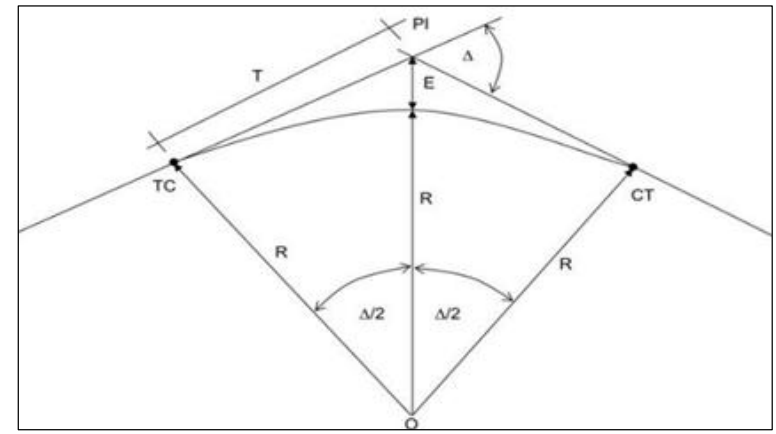

Gambar 2. Komponen FC Sumber: (Hendarsin, 2000)

Persamaan 1 hingga Persamaan 3 digunakan untuk perancangan lengkung lingkaran penuh.

$$
\begin{aligned}
T_{C} & =R_{C} \tan \frac{1}{2} \Delta \\
E_{C} & =T_{C} \tan \frac{1}{4} \Delta \\
L_{C} & =\frac{\Delta 2 \pi R_{C}}{360^{\circ}}
\end{aligned}
$$

\subsubsection{Lengkung Spiral - Lingkaran - Spiral (S-C-S)}

Menurut (Hendarsin, 2000), lengkung S-C-S merupakan lengkung peralihan berbentuk spiral yang menghubungkan bagian lurus dengan radius tak berhingga di awal spiral (kiri TS atau kanan ST) dan bagian berbentuk lingkaran dengan radius $\left(R_{C}\right)$ di akhir spiral (titik SC atau CS). Titik TS merupakan titik peralihan bagian lurus ke bagian berbentuk spiral, sedangkan titik SC merupakan titik peralihan bagian spiral ke bagian lingkaran.

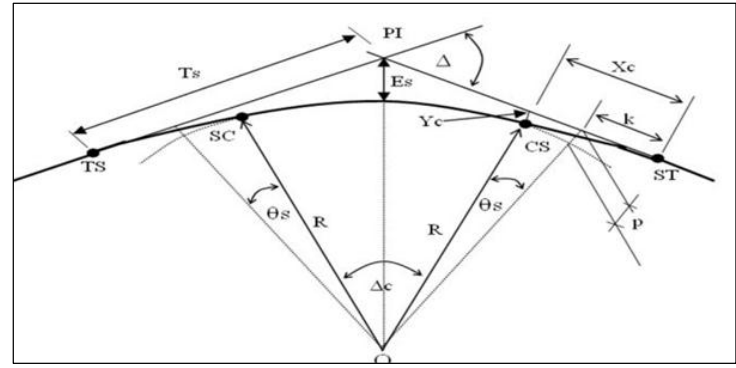

Gambar 3. Komponen S-C-S

Sumber : (Hendarsin, 2000)

Persamaan 4 hingga Persamaan 11 digunakan untuk perancangan lengkung spiral - lingkaran - spiral. 


$$
\begin{aligned}
& X_{S}=L_{S}\left(1-\frac{L_{S}^{2}}{40 R_{C}^{2}}\right) \\
& Y_{S}=\frac{L_{S}^{2}}{6 R_{C}} \\
& \theta_{S}=\frac{90}{\pi} \frac{L_{S}}{R_{C}} \\
& p=\frac{L_{S}}{6 R_{C}}-R_{C}\left(1-\cos \theta_{S}\right) \\
& k=L_{S}-R_{C}\left(1-\sin \theta_{S}\right) \\
& T_{S}=\left(R_{C}+p\right) \tan \frac{1}{2} \Delta+k \\
& p=\frac{L_{S}}{6 R_{C}}-R_{C}\left(1-\cos \theta_{S}\right) \\
& L_{C}=\frac{\left(\Delta-2 \theta_{S}\right)}{180} \times \pi \times R_{C}
\end{aligned}
$$

\subsubsection{Lengkung Spiral - Spiral (S-S)}

Menurut (Sukirman S. , 2015), lengkung S-S merupakan lengkung tanpa busur lingkaran, sehingga titik SC berimpit dengan titik CS seperti pada Gambar 4 dan disebut titik SCS, dengan Persamaan 12 dan Persamaan 13 perhitungan nilai $L_{s}$ minimum sebagai berikut.

$$
\begin{aligned}
& \theta_{S}=\frac{1}{2} \Delta \\
& L_{S}=\frac{\theta_{S} \pi R_{C}}{90}
\end{aligned}
$$

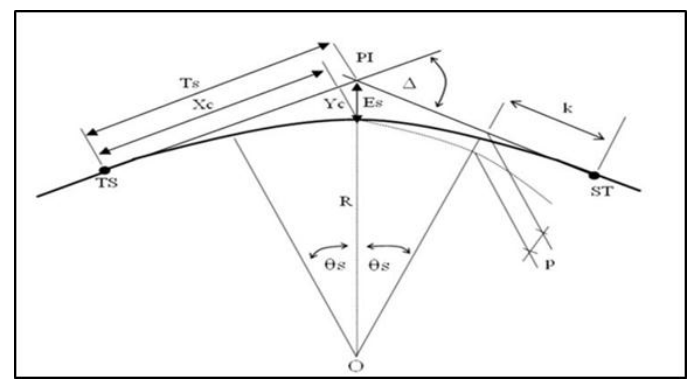

Gambar 4. Komponen S-S

Sumber: (Sukirman, 2015)

\subsection{Alinyemen Vertikal}

Menurut (Sukirman S. , 2015), alinyemen vertikal merupakan perancangan elevasi sumbu jalan pada setiap titik yang ditinjau, berupa profil memanjang. Pada alinyemen vertikal akan dijumpai kelandaian positif (tanjakan) dan kelandaian negatif (turunan) sehingga kombinasinya lengkung cembung dan lengkung cekung.

\subsubsection{Lengkung Vertikal Cekung}

Menurut (Sukirman S. , 2015), pergantian dari suatu kelandaian ke kelandaian yang lain menggunakan lengkung vertikal. Titik perpotongan dua bagian tangen vertikal dinamakan Titik Perpotongan Vertikal (TPV), dikenal dengan nama Point of Vertical Intersection (PVI) atau 
sering disebut Poin Perpotongan Vertikal (PPV). Nilai $K$ berdasarkan jarak pandang henti hasil hitungan. Adapun nilai $K$ setelah pembulatan untuk lengkung vertikal cekung terdapat pada Tabel 1. Nilai panjang lengkung vertikal berdasarkan jarak pandang henti pada Persamaan 14 berikut.

$$
L=K \times A
$$

Tabel 1. Nilai $K$ Berdasarkan Jarak Pandang Henti Lengkung Vertikal Cekung

\begin{tabular}{cccc}
\hline $\begin{array}{c}\text { Kecepatan Rencana } \\
{[\mathbf{k m} / \mathbf{j a m}]}\end{array}$ & $\begin{array}{c}\text { Jarak Pandang Henti } \\
{[\mathbf{m}]}\end{array}$ & \multicolumn{2}{c}{$\boldsymbol{K}=\boldsymbol{L} / \boldsymbol{A}$} \\
\cline { 3 - 4 } & 20 & 2,1 & Hitungan \\
\hline 20 & 35 & 5,1 & 6 \\
\hline 30 & 50 & 8,5 & 9 \\
\hline 40 & 65 & 12,2 & 13 \\
\hline 50 & 85 & 17,3 & 18 \\
\hline 60 & 105 & 22,6 & 23 \\
\hline 70 & 130 & 29,4 & 30 \\
\hline 80 & 160 & 37,6 & 38 \\
\hline 90 & 185 & 44,6 & 45 \\
\hline 100 & 220 & 54,4 & 55 \\
\hline 110 & 250 & 62,8 & 63 \\
\hline 120 & 285 & 72,7 & 73
\end{tabular}

(Sumber: AASHTO, 2004)

a. Kebutuhan drainase pada lengkung vertikal cekung

Lengkung vertikal cekung yang panjang dan relatif datar dapat menimbulkan masalah drainase apabila di sepanjang jalan tidak mengalir lancar. Untuk menghindari hal tersebut (AASHTO, 2004) maka perlu membatasi panjang lengkung vertikal tidak melebihi $51 \mathrm{~A}$.

b. Syarat kenyamanan penumpang

Gaya sentrifugal dan gravitasi pada lengkung vertikal cekung menimbulkan rasa tidak nyaman kepada penumpang. Maka, panjang lengkung vertikal cekung minimum dihitung sesuai Persamaan 15 berdasarkan (AASHTO, 2004) berikut.

$$
L=\frac{A V^{2}}{395}
$$

C. Syarat bentuk visual

(AASHTO, 2004) memberikan batasan bentuk lengkung vertikal dengan panjang minimum dihitung sesuai Persamaan 16 berikut.

$$
L=30 A
$$

\subsubsection{Lengkung Vertikal Cembung}

Menurut (Sukirman S. , 2015), lengkung vertikal cembung merupakan lengkung dimana titik PPV berada di atas permukaan jalan. Dalam perancangan alinyemen vertikan cembung, nilai $K$ dipengaruhi oleh jarak pandang henti dan jarak pandang mendahului seperti terlihat pada Tabel 2. 
Tabel 2. Nilai $K$ Berdasarkan Jarak Pandang Henti Lengkung Vertikal Cembung

\begin{tabular}{|c|c|c|c|c|c|c|}
\hline \multirow{2}{*}{$\begin{array}{l}\text { Kecepatan } \\
\text { Rencana } \\
\text { [km/jam] }\end{array}$} & \multirow{2}{*}{$\begin{array}{c}\text { Jarak Pandang } \\
\text { Henti } \\
\text { [m] }\end{array}$} & \multicolumn{2}{|c|}{$K=L / A$} & \multirow{2}{*}{$\begin{array}{c}\text { Kecepatan } \\
\text { Rencana } \\
{[\mathrm{km} / \text { jam }]}\end{array}$} & \multirow{2}{*}{$\begin{array}{c}\text { Jarak Pandang } \\
\text { Henti } \\
\text { [m] }\end{array}$} & \multirow[b]{2}{*}{$K=L / A$} \\
\hline & & Hitungan & Pembulatan & & & \\
\hline 20 & 20 & 0,6 & 1 & 30 & 200 & 46 \\
\hline 30 & 35 & 1,9 & 2 & 40 & 270 & 84 \\
\hline 40 & 50 & 3,8 & 4 & 50 & 345 & 138 \\
\hline 50 & 65 & 6,4 & 7 & 60 & 410 & 195 \\
\hline 60 & 85 & 11,0 & 11 & 70 & 485 & 272 \\
\hline 70 & 105 & 16,8 & 17 & 80 & 540 & 338 \\
\hline 80 & 130 & 25,7 & 26 & 90 & 615 & 438 \\
\hline 90 & 160 & 38,9 & 39 & 100 & 670 & 520 \\
\hline 100 & 185 & 52,0 & 52 & 110 & 730 & 617 \\
\hline 110 & 220 & 73,6 & 74 & 120 & 775 & 695 \\
\hline 120 & 250 & 95,0 & 95 & 130 & 815 & 769 \\
\hline 130 & 285 & 123,4 & 124 & & & \\
\hline
\end{tabular}

(Sumber: AASHTO, 2004)

Berdasarkan Tabel 2, nilai panjang lengkung vertikal berdasarkan jarak pandang henti dapat dihitung menggunakan Persamaan 14 di atas.

a. Kebutuhan drainase pada lengkung vertikal cembung

Menurut (Sukirman S. , 2015) tidak semua lengkung vertikal cembung bermasalah dalam hal drainase jalan. Akan tetapi, apabila panjang lengkung vertikal cembung relatif panjang dan datar sehingga menyebabkan kesulitan dalam masalah drainase seperti pemasangan kereb mengakibatkan air di samping jalan tidak mengalir lancar, maka AASHTO 2004 membatasi panjang lengkung vertical cembung tidak melebihi $51 \mathrm{~A}$.

b. Kenyamanan penumpang

Menurut (Sukirman S. , 2015) panjang lengkung vertikal cembung ditetapkan sedemikian rupa sehingga dapat memberikan rasa nyaman bagi pengemudi kendaraan. Lengkung vertikal cembung yang terlalu pendek akan memberikan rasa tidak nyaman kepada pengemudi akibat adanya gaya sentrifugal, terlebih-lebih jika dilalui dengan kecepatan tinggi. Menurut AASHTO 2004, batasan Panjang lengkung vertikal cembung minimum seperti Persamaan 17 berikut.

$$
L_{\min }=0,6 \mathrm{~V}
$$

\subsection{Kajian Terdahulu}

Penelitian ini disusun berdasarkan kajian terdahulu sebagai acuan, seperti (Triyono, Mudianto , \& Purwanti, 2019) dengan judul artikel penelitian Perbandingan Perencanaan Geometrik Jalan Menggunakan Aplikasi AutoCAD Civil 3D dengan Metode Bina Marga (Studi kasus : Ruas Jalan Bangurejo - Wates, Provinsi Lampung) dan penelitian yang disusun oleh (Kaharu, 2020) dengan judul Evaluasi Geometri Jalan Pada Ruas Jalan Trans Sulawesi Manado-Gorontalo Di Desa Botumoputi sepanjang $3 \mathrm{~km}$.

\section{METODE PENELITIAN}

Tinjauan ulang dilakukan terhadap alinyemen vertical dan horizontal dengan bantuan software AutoCAD Civil 3D 2018. Sementara itu, tahapan yang dilakukan sebgai berikut:

\subsection{Kajian Pustaka}

Penelitian ini dimulai dari identifikasi masalah dan penentuan topik yang diambil. Kajian kepustakaan yang berhubungan dengan perancangan geometri jalan berupa perancangan alinyemen vertikal, horizontal, stationing, superelevasi, galian dan timbunan sesuai 
dengan AASHTO 2004 pada ruas jalan Gudang - Cijambu, Kabupaten Sumedang, Jawa Barat dari STA $1+400$ s.d. STA 3+400.

\subsection{Pengumpulan Data}

Data yang diperoleh dari PT. Kriyasa Abdi Nusantara diolah dan digunakan untuk perancangan geometrik ruas jalan Gudang - Cijambu, Kabupaten Sumedang, Jawa Barat dari STA 1+400 s.d. STA 3+400.

\subsection{Perancangan Menggunakan Software AutoCAD Civil 3D}

Perancangan menggunakan software AutoCAD Civil 3D 2018 dengan tahapan sebagai berikut:

a. Persiapkan data peta kontur yang didapat dari Global Earth dan diolah ke Global Mapper lalu pindahkan peta tersebut pada software AutoCAD Civil 3D 2018.

b. Desain trase ruas jalan, alinyemen vertikal, horizontal dan superelevasi.

c. Hitung galian dan timbunan pada perencanaan ruas jalan yang dirancang.

\subsection{Perancangan Secara Manual}

Tahapan perancangan manual yaitu menghitung secara manual menggunakan pedoman berupa bahan ajar atau buku perancangan geometri jalan sesuai dengan peraturan (AASHTO, 2004).

\subsection{Pembahasan}

Hasil dari perancangan geometri jalan baru menggunakan software AutoCAD Civil 3D 2018 dibandingkan dengan data perhitungan konsultan dan perhitungan manual. Setelah dilakukan pembahasan maka dapat ditarik beberapa kesimpulan dan saran.

\section{PENGOLAHAN DAN ANALISIS DATA}

\subsection{Data Perancangan}

Perancangan geometri ruas jalan baru Gudang - Cijambu Sumedang dalam analisis perhitungan menggunakan Tipe Jalan 2 lajur 2 arah tanpa median, jenis medan pegunungan, fungsi jalan lokal sekunder, kecepatan rencana $20 \mathrm{~km} / \mathrm{jam}$, lebar perkerasan jalan $2 \times 2 \mathrm{~m}$, lebar bahu jalan $2 \times 1 \mathrm{~m}$, e bahu jalan $5 \%$, e normal melintang $3 \%$ dan kelandaian memanjang maksimal $10 \%$.

\subsection{Perancangan Alinyemen Horizontal Konsultan}

Perancangan alinyemen horizontal yang dilakukan oleh konsultan PT. Kriyasa Abdi Nusantara pada ruas jalan Gudang - Cijambu Sumedang STA $1+400$ s.d. STA 3+400 terdapat 22 lengkung. Data perancangan konsultan dapat dilihat pada Tabel 3 sampai dengan Tabel 5.

Tabel 3. Data Perancangan Konsultan PI 17 - PI 23

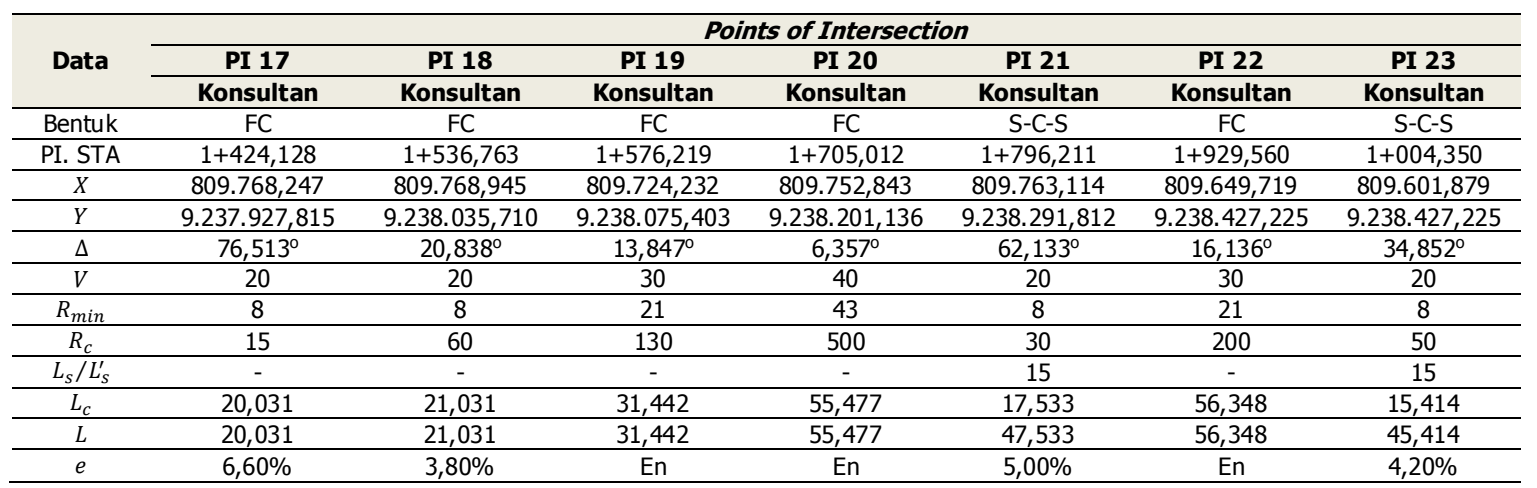


Tabel 4. Data Perancangan Konsultan PI 24 - PI 30

\begin{tabular}{|c|c|c|c|c|c|c|c|}
\hline \multirow{3}{*}{ Data } & \multicolumn{7}{|c|}{ Points of Intersection } \\
\hline & PI 24 & PI 25 & PI 26 & PI 27 & PI 28 & PI 29 & PI 30 \\
\hline & Konsultan & Konsultan & Konsultan & Konsultan & Konsultan & & \\
\hline Bentuk & S-C-S & S-C-S & S-C-S & S-C-S & FC & $\mathrm{FC}$ & S-C-S \\
\hline$X$ & $809.480,355$ & $809.447,670$ & $809.361,890$ & $809.317,827$ & $809.338,498$ & $809.362,252$ & $809.359,751$ \\
\hline$Y$ & $9.238 .461,201$ & $9.238 .578,305$ & $9.238 .653,579$ & $9.238 .834,813$ & $9.238 .893,862$ & $9.238 .939,807$ & $9.238 .998,471$ \\
\hline$\Delta$ & $58,785^{\circ}$ & $38,137^{\circ}$ & $35,067^{\circ}$ & $32,958^{\circ}$ & $8,046^{\circ}$ & $29,781^{\circ}$ & $83,312^{\circ}$ \\
\hline$R_{C}$ & 35 & 70 & 80 & 50 & 250 & 30 & 35 \\
\hline$L_{S} / L_{S}^{\prime}$ & 15 & 25 & 25 & 15 & - & - & 15 \\
\hline$L_{c}$ & 20,910 & 15,485 & 23,963 & 13,762 & 35,107 & 15,593 & 35,923 \\
\hline$L$ & 50,910 & 65,485 & 73,963 & 43,762 & 35,107 & 15,593 & 65,923 \\
\hline$e$ & $4,80 \%$ & $3,40 \%$ & $3,20 \%$ & $4,20 \%$ & En & $5,00 \%$ & $4,80 \%$ \\
\hline
\end{tabular}

Tabel 5. Data Perancangan Konsultan PI 31 - PI 38

\begin{tabular}{|c|c|c|c|c|c|c|c|c|}
\hline \multirow{3}{*}{ Data } & \multicolumn{8}{|c|}{ Points of Intersection } \\
\hline & PI 31 & PI 32 & PI 33 & PI 34 & PI 35 & PI 36 & PI 37 & PI 38 \\
\hline & Konsultan & Konsultan & Konsultan & Konsultan & Konsultan & Konsultan & Konsultan & Konsultan \\
\hline Bentuk & S-C-S & FC & FC & S-C-S & S-C-S & FC & FC & $\mathrm{FC}$ \\
\hline PI. STA & $2+795,139$ & $2+850,841$ & $2+908,348$ & $3+021,340$ & $3+073,876$ & $3+190,853$ & $3+293,858$ & $3+373,754$ \\
\hline$X$ & $809.269,385$ & $809.249,126$ & $809.249,365$ & $809.265,750$ & $809.311,234$ & $809.307,154$ & $809.327,948$ & $809.324,701$ \\
\hline$Y$ & $9.239 .005,102$ & $9.239 .063,804$ & $9.239 .121,728$ & $9.239 .233,556$ & $9.239 .264,805$ & $9.239 .843,833$ & $9.239 .485,865$ & $9.239 .565,998$ \\
\hline$\Delta$ & $66,763^{\circ}$ & $19,277^{\circ}$ & $8,099^{\circ}$ & $47,174^{\circ}$ & $57,456^{\circ}$ & $13,577^{\circ}$ & $13,949^{\circ}$ & $13,038^{\circ}$ \\
\hline$V$ & 20 & 30 & 30 & 20 & 20 & 30 & 40 & 30 \\
\hline$R_{\min }$ & 8 & 21 & 21 & 8 & 8 & 21 & 43 & 21 \\
\hline$R_{C}$ & 40 & 130 & 130 & 50 & 30 & 130 & 250 & 205 \\
\hline$L_{S} / L_{S}^{\prime}$ & 15 & - & - & 15 & 15 & - & - & - \\
\hline$L_{c}$ & 31,609 & 43,738 & 18,377 & 26,167 & 15,084 & 30,805 & 60,867 & 46,647 \\
\hline$L$ & 61,609 & 43,738 & 18,377 & 56,167 & 45,084 & 30,805 & 60,867 & 46,647 \\
\hline$e$ & $4,60 \%$ & En & En & $4,20 \%$ & $5,00 \%$ & En & En & En \\
\hline
\end{tabular}

\subsection{Perancangan Alinyemen Horizontal dengan AutoCAD Civil 3D}

Perhitungan lengkung horizontal yang ditinjau pada penelitian ini yaitu ruas jalan baru Gudang - Cijambu Sumedang STA 1+400 s.d. STA 3+400 dimana pada perancangan konsultan terdapat 22 tikungan yaitu $\mathrm{PI}_{17}$ s.d. $\mathrm{PI}_{38}$. Pada perancangan manual perubahan titik PI menjadi 9 tikungan seperti terlihat pada Gambar 6 dan Tabel 6 .

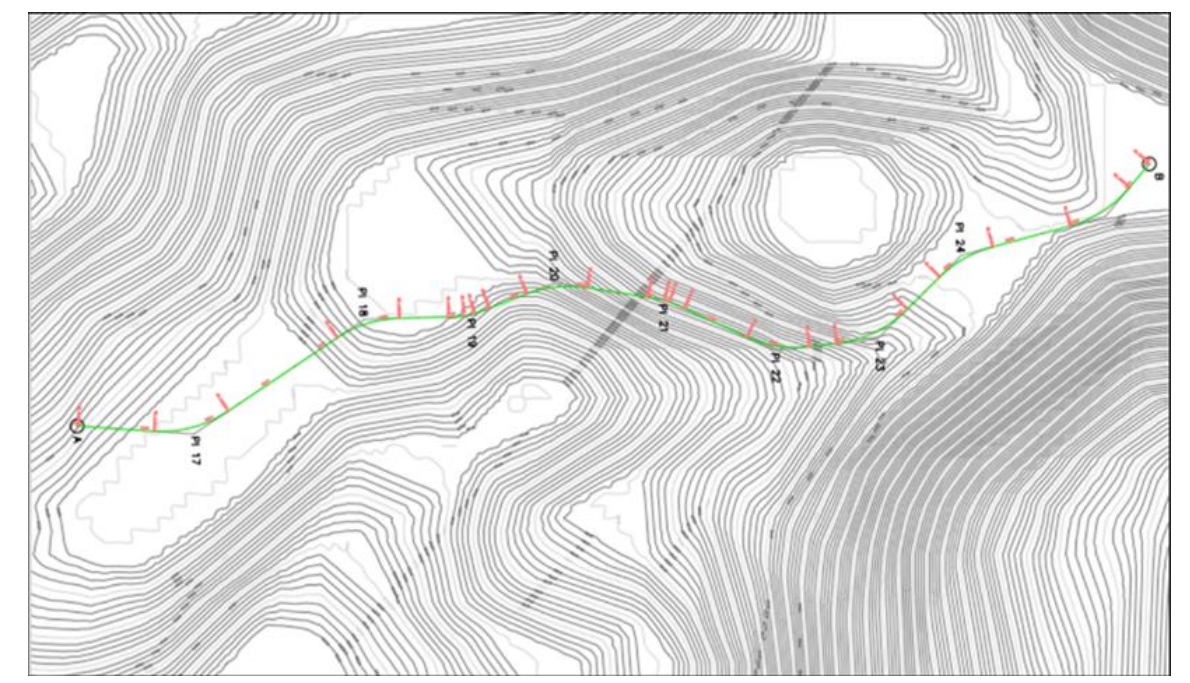

Gambar 6. Desain Lengkung Horizontal menggunakan AutoCAD Civil 3D 
Tabel 6. Hasil Perancangan Alinyemen Horizontal Manual dan AutoCAD Civil 3D

\begin{tabular}{|c|c|c|c|c|c|c|c|c|c|}
\hline \multirow{3}{*}{ Data } & \multicolumn{9}{|c|}{ Points of Intersection } \\
\hline & PI 17 & PI 18 & PI 19 & PI 20 & PI 21 & PI 22 & PI 23 & PI 24 & PI 25 \\
\hline & Konsultan & Konsultan & Konsultan & Konsultan & Konsultan & Konsultan & Konsultan & Konsultan & Konsultan \\
\hline Bentuk & FC & FC & S-C-S & FC & S-C-S & FC & FC & $\mathrm{FC}$ & FC \\
\hline PI. STA & $2+571,490$ & $2+873,030$ & $2+026,185$ & $2+162,185$ & $2+327,420$ & $2+505,345$ & $2+682,430$ & $2+825,555$ & $3+043,760$ \\
\hline$X$ & $809.736,849$ & $809.566,532$ & $809.561,964$ & $809.512,345$ & 809. 385,067 & $809.612,767$ & $809.596,075$ & $809.471,434$ & $809.413,935$ \\
\hline$Y$ & $9.238 .209,000$ & $9.238 .462,080$ & $9.238 .616,724$ & $9.238 .744,750$ & $9.238 .909,190$ & $9.239 .072,120$ & $9.239 .221,820$ & $9.239 .346,841$ & $9.239 .560,236$ \\
\hline$\Delta$ & $38^{\circ}$ & $32^{\circ}$ & $19^{\circ}$ & $30^{\circ}$ & $16^{\circ}$ & $31^{\circ}$ & $39^{\circ}$ & $30^{\circ}$ & $35^{\circ}$ \\
\hline$V$ & 20 & 20 & 20 & 20 & 20 & 20 & 20 & 20 & 20 \\
\hline$R_{\min }$ & 8 & 8 & 8 & 8 & 8 & 8 & 8 & 8 & 8 \\
\hline$R_{c}$ & 145 & 145 & 115 & 145 & 115 & 145 & 145 & 145 & 145 \\
\hline$T_{s} / T_{c}$ & 49,701 & 41,857 & 31,785 & 38,955 & 27,921 & 40,202 & 50,708 & 38,626 & 45,763 \\
\hline$E_{c} / E_{S}$ & 8,355 & 9,873 & 1,812 & 5,115 & 1,342 & 5,473 & 8,823 & 5,115 & 7,307 \\
\hline$\theta_{s}$ & 2,765 & 1,636 & 5,976 & 2,765 & 5,976 & 2,765 & 2,765 & 2,765 & 2,765 \\
\hline$\theta_{c}$ & - & - & 7,047 & - & 4,047 & - & - & - & - \\
\hline$L_{s} / L_{s}^{\prime}$ & 14 & 14 & 24 & 14 & 24 & 14 & 14 & 14 & 14 \\
\hline$L_{c}$ & 95,762 & 81,498 & 15,130 & 76,112 & 7,593 & 78,434 & 97,561 & 75,499 & 88,657 \\
\hline$L$ & 114,429 & 100,165 & 63,130 & 94,779 & 55,593 & 97,101 & 116,228 & 94,166 & 107,324 \\
\hline$e$ & $3,50 \%$ & $3,50 \%$ & $5,40 \%$ & $3,50 \%$ & $5,00 \%$ & $3,50 \%$ & $3,50 \%$ & $3,50 \%$ & $3,50 \%$ \\
\hline
\end{tabular}

\subsection{Perencanaan Alinyemen Vertikal Konsultan}

Perancangan yang dilakukan oleh konsultan PT. Kriyasa Abdi Nusantara mempunyai lengkung sebanyak 15. Data perancangan konsultan dapat dilihat pada Tabel 7 sampai dengan Tabel 8.

Tabel 7. Hasil Perancangan Alinyemen Vertikal Cembung Konsultan

\begin{tabular}{|c|c|c|c|c|c|c|c|c|c|c|c|c|}
\hline \multirow{3}{*}{$\begin{array}{c}\text { Konsultan } \\
\text { LV } \\
\text { Cembung }\end{array}$} & \multirow{3}{*}{$\begin{array}{c}g_{1} \\
{[\%]}\end{array}$} & \multirow{3}{*}{$\begin{array}{c}\boldsymbol{g}_{2} \\
{[\%]}\end{array}$} & \multirow{3}{*}{$\begin{array}{c}A \\
{[\%]}\end{array}$} & \multirow{3}{*}{$\begin{array}{c}L \\
{[\mathrm{~m}]}\end{array}$} & \multicolumn{8}{|c|}{ Syarat } \\
\hline & & & & & \multicolumn{4}{|c|}{ Drainase } & \multicolumn{4}{|c|}{ Kenyamanan } \\
\hline & & & & & $L$ & \multirow{8}{*}{$\leq$} & $L=51 A$ & Ket. & $L$ & \multirow{8}{*}{2} & $L=0,6 \mathrm{~V}$ & Ket. \\
\hline $\mathrm{PPV}_{1}$ & 6,896 & 3,890 & 3,006 & 40 & 40 & & 153,306 & $\mathrm{OK}$ & 40 & & 12 & $\mathrm{OK}$ \\
\hline $\mathrm{PPV}_{3}$ & 4,935 & 1,950 & 2,975 & 40 & 40 & & 151,725 & OK & 40 & & 18 & OK \\
\hline $\mathrm{PPV}_{4}$ & 1,950 & $-2,377$ & 4,327 & 40 & 40 & & 220,677 & OK & 40 & & 12 & OK \\
\hline $\mathrm{PPV}_{7}$ & 7,318 & 0,621 & 6,517 & 40 & 40 & & 332,367 & OK & 40 & & 12 & $\mathrm{OK}$ \\
\hline $\mathrm{PPV}_{10}$ & 6,164 & 1,394 & 4,770 & 60 & 60 & & 243,270 & OK & 60 & & 24 & $\mathrm{OK}$ \\
\hline $\mathrm{PPV}_{12}$ & 3,796 & 1,602 & 2,194 & 60 & 60 & & 111,894 & $\mathrm{OK}$ & 60 & & 18 & OK \\
\hline $\mathrm{PPV}_{14}$ & 3,255 & $-5,482$ & 8,737 & 40 & 40 & & 445,587 & $\mathrm{OK}$ & 40 & & 18 & OK \\
\hline
\end{tabular}

Tabel 8. Hasil Perancangan Alinyemen Vertikal Cekung Konsultan

\begin{tabular}{|c|c|c|c|c|c|c|c|c|c|c|c|c|c|c|c|c|}
\hline \multirow{3}{*}{ Konsultan LV Cekung } & \multirow{3}{*}{$\begin{array}{c}g_{1} \\
{[\%]}\end{array}$} & \multirow{3}{*}{$\begin{array}{c}g_{2} \\
{[\%]}\end{array}$} & \multirow{3}{*}{$\begin{array}{c}A \\
{[\%]}\end{array}$} & \multirow{3}{*}{$\begin{array}{c}L \\
{[\mathrm{~m}]}\end{array}$} & \multicolumn{12}{|c|}{ Syarat } \\
\hline & & & & & \multicolumn{4}{|c|}{ Drainase } & \multicolumn{4}{|c|}{ Kenyamanan } & \multicolumn{4}{|c|}{ Bentuk Visual } \\
\hline & & & & & $L$ & \multirow{9}{*}{$\leq$} & $L=51 A$ & Ket. & $L$ & \multirow{9}{*}{$\geq$} & $L=A V^{2} / 395$ & Ket. & $L$ & \multirow{9}{*}{$\geq$} & $L=30 A$ & Ket. \\
\hline $\mathrm{PPV}_{2}$ & 3,890 & 4,925 & $-1,035$ & 40 & 40 & & 52,785 & $\mathrm{OK}$ & 40 & & 1,000 & OK & 40 & & 31,050 & OK \\
\hline $\mathrm{PPV}_{5}$ & $-2,377$ & 0,953 & $-3,330$ & 40 & 40 & & 169,83 & OK & 40 & & 7,587 & OK & 40 & & 99,900 & TO \\
\hline $\mathrm{PPV}_{6}$ & 0,953 & 7,138 & $-6,185$ & 40 & 40 & & 315,435 & $\mathrm{OK}$ & 40 & & 14,100 & OK & 40 & & 185,550 & TO \\
\hline $\mathrm{PPV}_{8}$ & 0,612 & 4,489 & $-3,868$ & 40 & 40 & & 197,268 & OK & 40 & & 3,900 & OK & 40 & & 116,040 & TO \\
\hline $\mathrm{PPV}_{9}$ & 4,498 & 6,614 & $-2,116$ & 60 & 60 & & 107,916 & OK & 60 & & 2,100 & OK & 60 & & 63,480 & TO \\
\hline $\mathrm{PPV}_{11}$ & 1,394 & 3,796 & $-2,402$ & 60 & 60 & & 122,502 & OK & 60 & & 2,400 & OK & 60 & & 72,060 & TO \\
\hline $\mathrm{PPV}_{13}$ & 1,602 & 3,225 & $-1,653$ & 40 & 40 & & 84,303 & $\mathrm{OK}$ & 40 & & 1,700 & OK & 40 & & 49,590 & TO \\
\hline $\mathrm{PPV}_{15}$ & $-5,482$ & $-0,365$ & $-5,117$ & 60 & 60 & & 260,967 & OK & 60 & & 20,700 & OK & 60 & & 153,510 & TO \\
\hline
\end{tabular}

\subsection{Perancangan Alinyemen Vertikal Manual dan AutoCAD Civil 3D}

Perancangan alinyemen vertikal secara manual pada ruas jalan baru Gudang - Cijambu memiliki 9 buah lengkung. Perhitungan seluruh PVI dapat dilihat pada Tabel 9 dan Tabel 10.

Tabel 9. Hasil Perancangan Lengkung Vertikal Cembung Manual dan AutoCad Civil 3D

\begin{tabular}{|c|c|c|c|c|c|c|c|c|c|c|c|c|c|c|}
\hline \multirow{3}{*}{$\begin{array}{l}\text { Konsultan LV } \\
\text { Cekung }\end{array}$} & \multirow{3}{*}{$\begin{array}{c}g_{1} \\
{[\%]}\end{array}$} & \multirow{3}{*}{$\begin{array}{c}g_{2} \\
{[\%]}\end{array}$} & \multirow{3}{*}{$\begin{array}{c}A \\
{[\%]}\end{array}$} & \multirow{3}{*}{$\begin{array}{l}L_{J P H} \\
{[\mathrm{~m}]}\end{array}$} & \multicolumn{8}{|c|}{ Syarat } & \multirow{3}{*}{$\begin{array}{c}L \\
\text { dipilih }\end{array}$} & \multirow{3}{*}{$E_{v}$} \\
\hline & & & & & \multicolumn{4}{|c|}{ Drainase } & \multicolumn{4}{|c|}{ Kenyamanan } & & \\
\hline & & & & & $L_{J P H}$ & \multirow{7}{*}{$\leq$} & $\begin{array}{l}L \\
=51 A\end{array}$ & Ket. & $L_{J P H}$ & \multirow{7}{*}{$\geq$} & $\begin{array}{l}L \\
=0,6 \mathrm{~V}\end{array}$ & Ket. & & \\
\hline $\mathrm{PPV}_{3}$ & 3,47 & 2,66 & 0,81 & 0,81 & 0,81 & & 41,31 & OK & 0,81 & & 12 & OK & 41,31 & 0,001 \\
\hline $\mathrm{PPV}_{5}$ & 4,90 & 3,35 & 1,55 & 1,55 & 1,55 & & 79,05 & OK & 1,55 & & 12 & OK & 79,05 & 0,003 \\
\hline $\mathrm{PPV}_{6}$ & 3,35 & 2,75 & 0,60 & 0,60 & 0,60 & & 30,60 & OK & 0,60 & & 12 & OK & 30,60 & 0,000 \\
\hline $\mathrm{PPV}_{7}$ & 2,75 & 2,42 & 0,33 & 0,33 & 0,33 & & 16,83 & OK & 0,33 & & 12 & OK & 16,83 & 0,0001 \\
\hline $\mathrm{PPV}_{8}$ & 2,42 & 0,85 & 1,57 & 1,57 & 1,57 & & 80,07 & OK & 1,57 & & 12 & OK & 80,07 & 0,003 \\
\hline $\mathrm{PPV}_{9}$ & 0,85 & $-0,52$ & 1,37 & 1,37 & 1,37 & & 69,87 & OK & 1,37 & & 12 & OK & 69,87 & 0,002 \\
\hline
\end{tabular}


Tabel 10. Hasil Perancangan Lengkung Vertikal Cekung Manual dan AutoCad Civil 3D

\begin{tabular}{|c|c|c|c|c|c|c|c|c|c|c|c|c|c|c|c|c|c|c|}
\hline \multirow{3}{*}{ Konsultan LV Cekung } & \multirow{3}{*}{$\begin{array}{c}g_{1} \\
{[\%]}\end{array}$} & \multirow{3}{*}{$\begin{array}{c}g_{2} \\
{[\%]}\end{array}$} & \multirow{3}{*}{$\begin{array}{c}A \\
{[\%]}\end{array}$} & \multirow{3}{*}{$\begin{array}{l}\boldsymbol{L}_{\text {IPH }} \\
{[\mathrm{m}]}\end{array}$} & \multicolumn{12}{|c|}{ Syarat } & \multirow{3}{*}{$L$ dipilih } & \multirow{3}{*}{$E_{v}$} \\
\hline & & & & & & & ainase & & & & nyamanan & & & & uk Visual & & & \\
\hline & & & & & $L_{P P H}$ & \multirow{4}{*}{$\leq$} & $L=51 A$ & Ket. & $L_{\text {PPH }}$ & \multirow{4}{*}{$\leq$} & $L=A V^{2} / 395$ & Ket. & $L_{J P H}$ & \multirow{4}{*}{$\geq$} & $L=0,6 \mathrm{~V}$ & Ket. & & \\
\hline $\mathrm{PPV}_{1}$ & 0,18 & 2,30 & $-2,12$ & 6,36 & 6,36 & & 108,12 & $\mathrm{OK}$ & 6,36 & & 2,15 & OK & 6,36 & & 63,60 & $\mathrm{OK}$ & 63,60 & 0,1685 \\
\hline $\mathrm{PPV}_{2}$ & 2,30 & 3,47 & $-1,17$ & 3,51 & 3,51 & & 59,67 & OK & 3,51 & & 1,19 & $\mathrm{OK}$ & 3,51 & & 35,10 & $\mathrm{OK}$ & 35,10 & 0,0513 \\
\hline $\mathrm{PPV}_{4}$ & 2,66 & 4,90 & $-2,24$ & 6,72 & 6,72 & & 114,24 & OK & 6,72 & & 2,27 & OK & 6,72 & & 67,20 & OK & 67,20 & 0,1882 \\
\hline
\end{tabular}

\subsection{Perbandingan Galian Timbunan Konsultan dan Perancangan Geometri Jalan} Baru

Perhitungan galian dan timbunan pada perancangan geometri jalan baru ruas jalan Gudang Cijambu menggunakan software AutoCAD Civil 3D diperoleh data seperti tertera pada Tabel 11.

Tabel 2. Selisih Volume Galian dan Timbunan dengan Manual dan AutoCAD Civil 3D

\begin{tabular}{cccc}
\hline Perhitungan & $\begin{array}{c}\text { Timbunan } \\
{\left[\mathbf{m}^{3}\right]}\end{array}$ & $\begin{array}{c}\text { Galian } \\
{\left[\mathbf{m}^{3}\right]}\end{array}$ & $\begin{array}{c}\text { Selisih } \\
{\left[\mathbf{m}^{3}\right]}\end{array}$ \\
\hline Konsultan & $137.524,12$ & $2.314,64$ & $135.209,48$ \\
\hline Perancangan Geometri Jalan Baru & $40.866,53$ & $52.265,38$ & $11.398,85$ \\
\hline
\end{tabular}

\section{KESIMPULAN DAN SARAN}

\subsection{Kesimpulan}

Perancangan menggunakan software AutoCAD Civil 3D 2018 dilakukan untuk membandingkan antara perancangan geometri ruas jalan baru Gudang - Cijambu dengan perancangan yang telah dibuat oleh konsultan PT. Kriyasa Abdi Nusantara, dengan titik awal dan titik akhir yang sama. Setelah dilakukan analisis dan perhitungan, maka dapat ditarik kesimpulan sebagai berikut:

1. Menurut Kemen PU No.19/PRT/M/2011 untuk kelas jalan kecil lebar jalur minimal 5,5 meter; paling sedikit 2 lajur untuk 2 arah dan melayani lalu lintas sesuai fungsi jalan lokal namun perancangan geometri ruas jalan baru Gudang - Cijambu menggunakan lebar jalur $2 \times 2$ meter disesuaikan dengan perancangan jalan konsultan tidak memenuhi persyaratan Kemen PU No.19/PRT/M/2011.

2. Menurut Kemen PU No.19/PRT/M/2011, kecepatan rencana dengan fungsi jalan lokal sekunder adalah $30-60 \mathrm{~km} / \mathrm{jam}$. Perancangan geometri ruas jalan baru Gudang Cijambu menggunakan kecepatan rencana $20 \mathrm{~km} / \mathrm{jam}$ disesuaikan dengan perancangan konsultan tidak memenuhi persyaratan Kemen PU No.19/PRT/M/2011.

3. Hasil perancangan geometri jalan baik secara manual maupun menggunakan AutoCAD Civil 3D menghasilkan 9 buah lengkung horizontal yaitu 7 lengkung FC, 2 buah lengkung S-C-S sedangkan perancangan konsultan sebanyak 22 buah lengkung horizontal yaitu 12 buah lengkung FC dan 10 lengkung S-C-S.

4. Perubahan lengkung vertikal pada perancangan geometri jalan baru sebanyak 9 buah lengkung vertikal yaitu 6 buah lengkung vertikal cembung dan 3 buah lengkung vertikal cekung, sedangkan perancangan konsultan sebanyak 15 buah lengkung vertikal yaitu 7 buah lengkung vertikal cembung dan 8 buah lengkung vertikal cekung.

5. Perubahan panjang trase jalan yang semula 2.000 meter menjadi $1.747,41$ meter.

6. Perancangan geometri jalan menggunakan data konsultan didapatkan selisih jumlah volume galian dan volume timbunan sebanyak $135.209,48 \mathrm{~m}^{3}$ lebih banyak dari perancangan geometri jalan baru dengan selisih jumlah volume galian dan timbunan sebanyak $11.398,85 \mathrm{~m}^{3}$. 


\subsection{Saran}

Saran yang dapat disampaikan untuk bahan pertimbangan penelitian selanjutnya adalah:

1. Perlunya penyiapan data secara lengkap seperti data mentah, peta digital dan software yang bertujuan untuk memudahkan pekerjaan penelitian. Data peta digital bisa didapat dari pihak konsultan atau didapat dari Global Earth.

2. Penarikan trase jalan baik alinyemen horizontal maupun alinyemen vertikal sangat mempengaruhi hasil jumlah volume galian dan timbunan. Penarikan trase jalan diusahakan tidak memotong kontur tetapi mengikuti kontur dengan elevasi yang sama sehingga menghasilkan volume galian dan timbunan lebih sedikit.

3. Dalam perancangan geometri ruas jalan baru Gudang - Cijambu seharusnya memenuhi persyaratan Kemen PU No.19/PRT/M/2011 untuk kecepatan rencana dan lebar jalan, namun pada kajian ini disesuaikan dengan perancangan konsultan karena hanya akan membandingkan volume galian dan timbunan saja.

\section{UCAPAN TERIMA KASIH}

Penulis mengucapkan terima kasih kepada pihak yang telah membantu dalam pengambilan data kepada Dinas Pekerjaan Umum dan Penataan Ruang, Kabupaten Sumedang dan Konsultan PT. Kriyasa Abdi Nusantara.

\section{DAFTAR RUJUKAN}

AASHTO. (2004). A Policy on Geometri Design of Highways and Streests. Washington, D.C. Hendarsin, S. L. (2000). Perencanaan Teknik Jalan Raya. Bandung: Politeknik Negeri Bandung. Kaharu, F. (2020). Evaluasi Geometrik Jalan Pada Ruas Jalan Trans Sulawesi ManadoGorontalo Di Desa Botumoputi. Jurnal Sipil Statik Vol.8, 359.

Sukirman, S. (2015). Dasar-Dasar Perencanaan Geometrik Jalan. Bandung: PT. Karyamanunggal Lithomas.

Triyono, T., Mudianto , A., \& Purwanti, H. (2019). Perbandingan Perencanaan Geometri Jalan Menggunakan Aplikasi AutoCad Civil 3D dengan Metode Bina Marga. Evaluasi Geometri Jalan (Studi kasus : Ruas Jalan Bangunrejo - Wates, Provinsi Lampung), 11.

Departemen Pekerjaan Umum. (2011). Persyaratan Teknis Jalan dan Kriteria Perencanaan Teknis Jalan No 19/PRT/2011. Jakarta: Departemen Pekerjaan Umum. 